NBER WORKING PAPER SERIES

\title{
THE STRUCTURE OF EARLY CARE AND EDUCATION IN THE UNITED STATES: HISTORICAL EVOLUTION AND INTERNATIONAL COMPARISONS
}

\author{
Ann Dryden Witte \\ Marisol Trowbridge \\ Working Paper 10931 \\ http://www.nber.org/papers/w10931
}

\author{
NATIONAL BUREAU OF ECONOMIC RESEARCH \\ 1050 Massachusetts Avenue \\ Cambridge, MA 02138 \\ November 2004
}

The views expressed herein are those of the author(s) and do not necessarily reflect the views of the National Bureau of Economic Research.

(C) 2004 by Ann Dryden Witte and Marisol Trowbridge. All rights reserved. Short sections of text, not to exceed two paragraphs, may be quoted without explicit permission provided that full credit, including (C) notice, is given to the source. 
The Structure of Early Care and Education in the United States:

Historical Evolution and International Comparisons

Ann Dryden Witte and Marisol Trowbridge

NBER Working Paper No. 10931

November 2004

JEL No. H5, H6, I2, I3

\begin{abstract}
$\underline{\text { ABSTRACT }}$
Most European governments have universal, consolidated, education-based ECE programs that are available from early in the morning to late in the evening throughout the year. European ECE programs are uniformly of high quality, generally last at least three years, and are funded to serve all children. The US ECE system is composed of three separate programs (Head Start, PreKindergarten (Pre-K) and the child care voucher program) targeted to low-income children. With a few notable exceptions, US ECE programs are funded to serve less than half of the eligible children. US ECE programs developed quite separately. They have different goals, different funding sources, different administrations and policies, and generally last for an academic year or less. Pre-K and Head Start operate only 3 to 6 hours a day and are open only during the academic year. The average quality of US ECE programs is generally much lower than the average quality of European ECE programs. Further, the quality of US ECE programs varies widely even within local areas. Although the US has greatly increased expenditures on ECE, US governments pay only $40 \%$ of the costs of ECE, while European governments pay $70 \%$ to $90 \%$ of the costs of ECE. None of the major US ECE programs simultaneously provides work supports for parents, child development opportunities for children and preparation for school for low-income children. The evidence suggests that the US ECE system is neither efficient nor equitable. Consolidation of funding and administration of current US ECE programs could substantially lower transaction costs for parents and provide more stable care arrangements for children. Increased funding could improve the quality of existing programs, extend hours and months of operation, and make care available to all eligible families. Both the evaluation literature and the European experience suggest that such a consolidated, well-funded system could be successful in preparing poor children for school. Further, the benefits of such a program could well exceed the costs since it is precisely low-income children that benefit most from stable, high-quality ECE. However, such a targeted program will have neither the positive peer group effects nor the social-integration benefits of universal ECE programs.

Ann Dryden Witte

Department of Economics

Wellesley College

Wellesley, MA 02481

and NBER

awitte@wellesley.edu

Marisol Trowbridge

Wellesley College
\end{abstract}




\section{Introduction}

Recent economic research suggests that there is a high return to early care and education (ECE) and a much lower return to compensatory interventions later in the lifecycle. This research also highlights the importance of both cognitive and non-cognitive skills that are formed early in the life cycle for educational achievement, earnings and other dimensions of socioeconomic success (Carneiro \& Heckman, 2003).

During the last ten years, the federal government has twice included early care and education (ECE) as a component of a broader reform agenda. In 1996, funding for child care vouchers was expanded as part of the much broader welfare reform agenda. Under welfare reform, mothers receiving cash assistance were required to work or be in other approved activities. Further, time limits were placed on the receipt of cash assistance. Child care vouchers were made available to help these mothers pay for their children's care. In 2002 under the Good Start, Grow Smart initiative, the goals of the Head Start program was directed to serve the needs of the education reform embedded in the No Child Left Behind law. Under Good Start, Grow Smart, the Head Start program is to prepare children to read and succeed in school. States had much earlier developed PreKindergarten (Pre-K) programs as part of earlier school reform efforts.

In the US, ECE has been a byproduct or other policy initiatives. It has not been seen as a central and important area for careful policy formation. As a result, the US has what the Committee for Economic Development calls a "patchwork of early care and education opportunities" (Committee for Economic Development, 2002, p. 6). A recent OECD report goes further and states: "the present patchwork of services, regulations and funding sources leads to confusion, uneven quality and inequality of access. (OECD, 2004b, pp. 184).

European governments have established ECE programs that provide work supports for parents, provide child development opportunities for children and prepare all children for school. The US has established three separate ECE programs (Head Start, Pre-K and the child care voucher program) as offshoots of other major policy initiatives. Each programs has is own funding sources, goals, administration, standards, policies and evaluation literature.

As pointed out by the Committee for Economic Development (CED), effective policy making for early care and education is hampered by the lack of a comprehensive view of publicly funded early care and education programs. Research and data collection is generally limited to a single program and is often focused on a specific period or policy regime. In this paper, we pull together information for all three programs. We draw these diverse literatures together to provide an assessment of the US system as a whole.

To briefly preview our conclusions, the US ECE system does not reach all potential beneficiaries, often provides unstable care with limited education or developmental content, frequently imposes high transaction costs on low-income families and requires three separate administrative structures. None of the major US ECE programs simultaneously provides work supports for parents, child development opportunities for children and school preparation for low-income children. US ECE programs have benefits for low-income families that receive services, and there appear to be social benefits emanating from these programs as well. However, we have no convincing evidence that the social benefits of any of the three US ECE programs 
outweigh the social costs. We do have evidence that more cohesive, stable, intensive and higher quality ECE programs have social benefits that outweigh their higher social costs.

By providing developmental activities to low-income children and work supports to low-income families, US ECE programs increase vertical equity in the US. However, we find glaring vertical and horizontal inequities in the outcomes that result from the current US ECE system. As far as vertical equity is concerned, only $45 \%$ of three- to five-year-old children in the US living in low-income families are enrolled in preschool, while $75 \%$ of three to five year olds in higher income families attend preschools. As far as horizontal equity is concerned, fewer than half of all eligible low-income children receive services from Head Start, Pre-K programs or have preschool care purchased with a child care voucher.

The paper is structured as follows. In the next section, we briefly review the way in which US and European government policies affect the way in which preschool children are cared for. The third section provides a brief review of the development of early care and education in the US, including Head Start, Pre-Kindergarten, and the child care voucher program. In section 4, we discuss the wide array of methods currently used to fund US early care and education. In section 5, we consider major issues facing the current US ECE "system": (1) the goals and structure of US early care and education programs, (2) the costs of having three distinct, generally under-funded ECE programs, (3) the consolidation or coordination of different programs, (3) equality of access and (4) the effectiveness of early care and education programs. The final section of the paper contains our conclusions.

\section{Public Roles in Early Care \& Education}

Governments in most developed countries have played a growing role in early care and education since the 1970s when the labor force participation of women with children began to rise rapidly. Governments affect the way in which preschool children are cared for and educated through: (1) parental leave policies, (2) tax policies and (3) expenditure policies. To set the stage for our discussion of major US policies regarding early care and education, we briefly describe and contrast major European and US policies in these three area.

\section{Parental Leave Policies}

European countries make far greater use of parental leave than the US. Maternity leaves were enacted in Germany and France more than a century ago to protect the physical health of working women at the time of child birth. Child rearing payments, parental leaves and paternity leaves began during the 1960s and developed rapidly during the 1970s, as the labor force participation rates of European women began to rise rapidly. European leave policies tend to be universal rather than targeted (e.g., available only for low-income, single parents).

Today, all new parents in many European countries have the option of taking a period of paid leave after the birth of a child. Some countries also provide childrearing payments that can extend until the child is 3 years old. For example, Finland provides 18 weeks of maternity leave and 26 weeks of parental leave, with the stay at home parent paid $70 \%$ of prior earnings. In Finland and Norway, parents have the option of a 
subsidized place in child care or a cash benefit of equivalent value for children under age 3.

In Europe, parental leaves are paid for through temporary disability programs, unemployment insurance programs, family allowance systems or as a separate social insurance benefit. See Kamerman (2000) for a description of parental leave policies and the Clearinghouse on International Development in Child, Youth and Family Policies for updated information (2002).

The US did not have a national family leave policy until 1993. ${ }^{1}$ However, the Aid to Families with Dependent Children program was originally set up to allow divorced and unmarried mothers to stay home and care for their children (Helburn \& Bergmann, 2002). Under the 1993 Family and Medical Leave Act (FMLA), new parents are entitled to 12 weeks of job-protected leave if they work at firms with at least 50 employees and worked at lest 1,250 hours the prior year. Fewer than half of US private sector workers are eligible for leaves under FMLA. Further, leaves under FMLA are unpaid. Take-up rates for FMLA are far lower than take-up rates for the more generous European programs (Waldfolgel, 2001).

The potential impacts of parental leave are many: (1) health effects for family members, particularly the mother and child; (2) static and dynamic employment and income effects particularly for the mother; (3) budgetary impacts for governments and (4) business impacts for employers. Research on the nature and extent of these impacts is limited. Ruhm (1998) finds that parental leave guarantees raise the employment of women, but at longer durations, they may be paid for through the receipt of lower relative wages. In a later article, Ruhm (2000) concludes that the substantial child health benefits associated with parental leaves may make it a cost-effective way of improving child health. Overall, existing research suggests that parental leaves of more than the 12 weeks, provided by FMLA, but less than one year may be economically efficient. The European and US experience suggest that leaves will have to provide substantial wage replacement (about $50 \%$ to $75 \%$ ) to encourage substantial numbers of parents to use parental leaves.

\section{Tax Policy}

Child-related tax policies are not generally targeted to young children, but rather are available to all children in school or below the age of majority. European countries tend to have universal child or family allowances and to make more limited use of tax deductions and tax credits. See Clearinghouse of International Developments in Child, Youth and Family Policies (2002) for details.

By way of contrast the US has no child or family allowance, but it has exemptions, deductions and credits related to children. Most of these US tax policies depend on family income. For example, the US Child Tax Credit is up to $\$ 1000$ per child under 17. The full credit is available to married families with incomes below $\$ 110,000$ and single families with incomes below $\$ 75,000$. The credit may be partially refundable for working families with low-incomes.

In 2003, the US Dependent Care Tax Credit (DCTC) allowed a non-refundable credit of from $20 \%$ to $35 \%$ of qualifying care expenses up to $\$ 3000$ for one child and

\footnotetext{
${ }^{1}$ Some states enacted leave statutes prior to 1993. In 1989, 12 states had maternity leaves and 11 states had parental leaves (Clearinghouse on International Developments in Child, Youth and Family Policies, 2002).
} 
$\$ 6000$ for two children under the age of $13 .^{2}$ For a family with one child in care and income below $\$ 15,000$, the maximum amount of the credit would be $\$ 1020$. However, most families with income below $\$ 15,000$ will owe no taxes, will not spend $\$ 3000-\$ 6000$ on child care and thus will not benefit from the DCTC. For a family with one child in care and incomes above $\$ 43,000$, the maximum amount of the credit would be $\$ 600$. Most families with incomes above $\$ 43,000$ will pay tax, may pay $\$ 3,000$ for child care and may claim the DCTC. Indeed, the use of the DCTC rises with income. Altshuler and Schwartz (1996) find that about $1 \%$ of the total DCTC payments are claimed by taxpayers in the lowest two income deciles and $32 \%$ of the credits are claimed by taxpayers in the top two income deciles.

Tax expenditures related to the DCTC amounted to a little less than $\$ 1$ billion in 1980 , but they had risen to almost $\$ 4$ billion by 1988 (Hayes, Palmer \& Zaslow, 1990). In that year the credit accounted for over half of all federal expenditures on early care and education. Unlike the Earned Income Tax Credit, the DCTC is not indexed. Accordingly, from 1981 to 2003 , creditable child care expenses were limited to $\$ 2,400$ for one child and $\$ 4,800$ for two or more children. During the same period, the percent of eligible expenses that could be claimed ranged from $30 \%$ for families with incomes below $\$ 10,000$ to $20 \%$ for families with incomes above $\$ 28,000$. By 1999 , the total federal credit was down to $\$ 2.7$ billion. As the value of the tax credit declined, the value of direct government expenditures on child care increased rapidly.

\section{Expenditure Policies}

Most European governments invest substantially more funds in early care and education than the US. In 1999, the US was in a seven-way tie for $13^{\text {th }}$ place out of 30 OECD countries in the percent of GDP devoted to early care and education. The US spent $.4 \%$ of GDP on early care and education, while Norway, Hungary and Denmark spent $.8 \%$ of GDP. ${ }^{3}$ See Heymann, et al. (2004).

European and US approaches to early care and education are quite different. European governments tend to provide universal, publicly-provided early care and education (ECE) for all children 3 to 6 years old. The quality of care tends to be relatively uniform within a country, and quality tends to be high overall. However, child/staff ratios vary widely across countries, with some countries (e.g., Finland) having ratios substantially below those in the US and other countries having ratios substantially higher (e.g., France). Staff credentials are uniformly higher in Western European countries than in the US. For example, Germany provides universal ECE for all children 3-6 through the education ministry, and $85 \%$ of 3-6 year olds participate in the program. The maximum child/staff ratio allowed ranges from 10 to 14 children per teacher across regions. Teachers are required to have 3 to 4 years of post-secondary education.

\footnotetext{
2 Many states also offer dependent care tax credits or deductions. These credits/deductions are generally a proportion of the federal credit, and some states have refundable credits (e.g., Colorado, Nebraska, and New York). See pp. 35-37 of Mitchell, Stoney and Dichter (2001) for details of state tax programs related to early care and education.

${ }^{3}$ These numbers do not control for the proportion of the population under 6 . With its higher fertility rate the US has a larger proportion of children under 6 then most European countries.
} 
Some European governments require no parental co-payment for ECE, while others require parental payments of from $10 \%$ to $30 \%$ of the cost of ECE. For example, Germany requires that parents pay from $16 \%$ to $20 \%$ of ECE costs, with the payment depending on family income. European ECE programs tend to be open year round and to run from early in the morning until late in the evening. For example, the Swedish ECE program is open from 6:30 A.M. to 6 P.M. all year. See Clearinghouse on International Developments in Child, Youth and Family Policies (2004a \& 2004b) for details regarding ECE policies.

European programs for children ages 0 to 3 are usually distinct from those for older preschool children. Given parental leave policies, there is less need for ECE for many younger children. For example, in France ECE for children ages 0-3 is provided by the health and welfare system, while ECE for children 3-6 is provided by education system. Publicly provided ECE for children 0-3 is only available if there is a need for such care (e.g., parents are working). ${ }^{4}$ In France, twenty nine percent of children 0 to 3 are enrolled in ECE, the highest level of enrollment in Western Europe.

ECE programs in the US are overwhelmingly targeted to children in economically disadvantaged families. The US government funds three major ECE programs: (1) Head Start, (2) Pre-Kindergarten and (3) the child care voucher program. These three programs have different sources of funding, different administrative structures and policies, and different minimum standard regulations. With few exceptions, the programs do not provide ECE for all eligible children whose parents want their children to participate. US parents pay a much larger portion of the cost of ECE than European parents. For example, in 1995, families provided 60\% of the cost of childcare (Mitchell, et. al., 2001). The OECD estimates that the federal government paid $25 \%$ and state and local governments paid $15 \%$ of the remaining costs (OECD, 2002). Finally, as we will detail below, US ECE programs often do not provide full-day, full-year care and are of highly varying quality.

Figure 1 gives US federal expenditures on ECE from 1962 through 2002 in billions of 2002 \$US. We provide estimates of spending on child care that both exclude and include funding for the Social Service Block Grant (SSBG). We know that a portion of SSBG funds are spent on child care, but we don't know on an annual basis what proportion. In 1990, 16\% of SSBG funding was used for ECE (Stoney \& Greenberg, 1996). Thus, actual expenditures on ECE is closer to the bottom than to the top line on the graph.

As can be seen in Figure 1, US federal government spending on early care and education has grown rapidly since the beginning of welfare reform in the late 1980s. These increases stemmed both from expansions of the child care voucher program and expansions of Head Start. Federal government expenditures on Head Start and on the child care voucher program were \$1,206 million in fiscal year (FY) 1988. By FY2002, federal expenditures on Head Start and the child care voucher program were between $\$ 13$ and $\$ 15$ billion, with approximately half of these expenditures being for Head Start and half for the child care voucher program. Spending on the child care voucher program

\footnotetext{
${ }^{4}$ Two year olds are gradually being shifted into the universal care program.
} 
include spending from the Child Care Development Fund (CCDF), transfers from TANF to CCDF and direct child care expenditures by TANF (Trowbridge \& Witte, 2004a). ${ }^{5}$

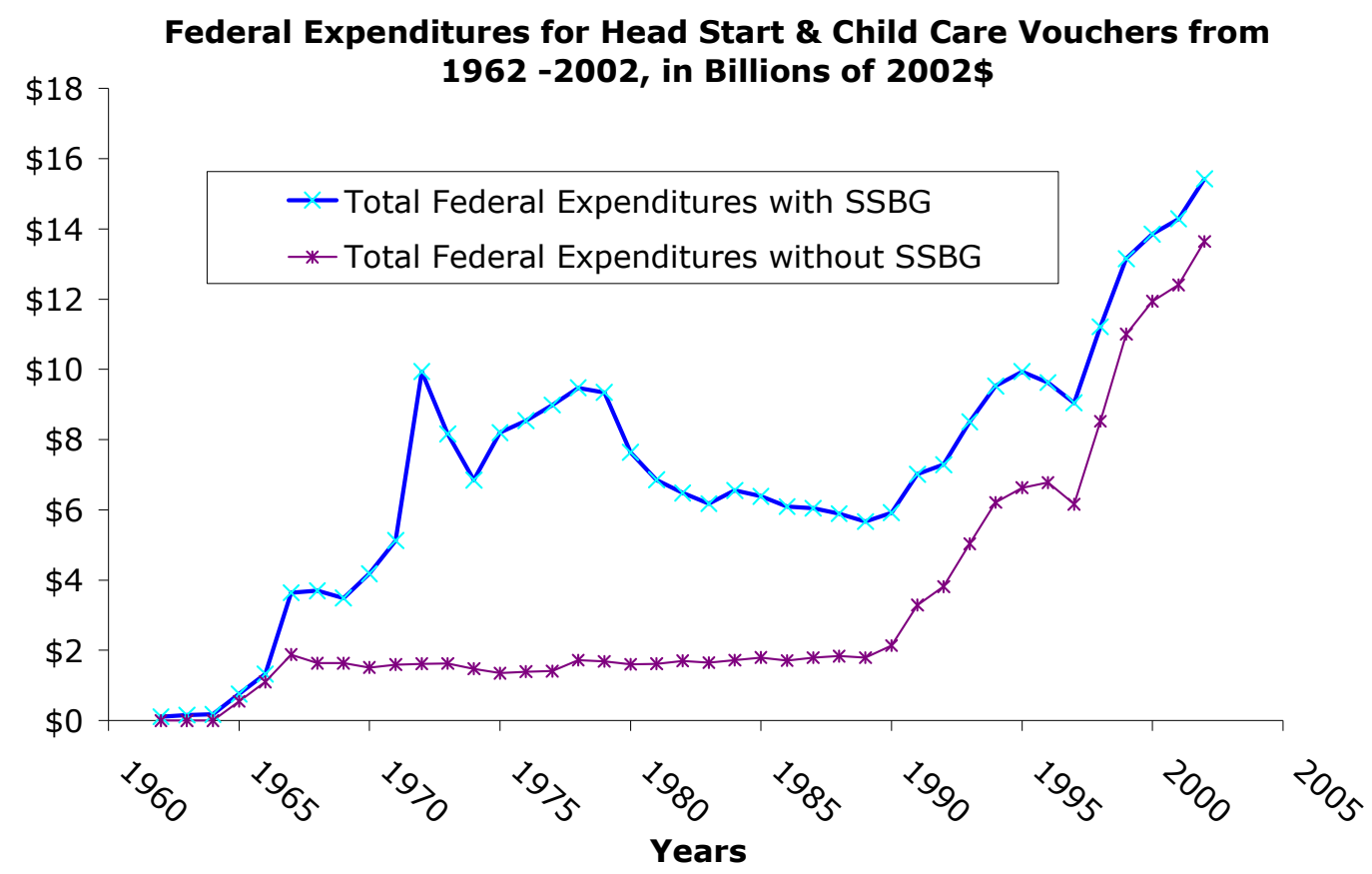

There is far less information on state expenditures for ECE. Some states substantially supplement federal funding for Head Start. For example, in 1998, states provided \$174 million to Head Start programs, in part to meet federally required local match requirements (Novack, 1999). However, a number of states such as Ohio provided substantial funding above match requirements.

Federal rules encourage states to provide CCDF funding by Maintenance of Effort (MOE) and matching fund requirements for some CCDF funding. CCDF funding is of three types. Two types of funding, called mandatory spending and discretionary spending, are $100 \%$ federal funds. The third type of funding, called matching funding, requires that states maintain the level of child care spending in either FY1994 or FY1995. This requirement is known at the maintenance of effort (MOE) requirement. States that meet the MOE requirement are eligible for matching funding. To obtain this funding, states must match federal expenditures at the Federal Medical Assistance Percentage (FMAP) rate. In FY2002, states expended \$989 million in general revenue to meet the MOE. While in the early years of the CCDF program, all states met their MOE requirements, by FY2002 eight states failed to meet the MOE requirement. The MOE shortfall in FY2002 was \$129 million. Further, many more states used Pre-K expenditures to meet the MOE requirement in FY2002 than in the early years of the

\footnotetext{
${ }^{5}$ The numbers include TANF spending on child care subsidies. The numbers given do not include federal funds used for Pre-K programs since we were unable to find any reporting of federal funding for Pre-K.
} 
CCDF program. States provided $\$ 898$ million in matching funds in FY2002 and failed to obligate $\$ 23$ million in matching funds.

We know that some states provide funds to the CCDF voucher program in excess of their MOE and matching requirements either to ensure that all eligible families that request a voucher receive one (e.g., Illinois, Rhode Island) or to increase the quality of care purchased with CCDF vouchers. However, we only have information on the amount of such state funding for seventeen states (Collin, et al., 2000). In FY 1999, these seventeen states allocated both state general revenue and revenue from child protective services to child care vouchers. In total these seventeen states allocated $\$ 858$ million in general revenue and $\$ 43$ million in child protective service funding to the child care voucher program.

In 1996 when previous child care voucher programs were consolidated and all direct voucher funding was passed to the states in a block grant, there was fear that there would be a "race to the bottom." We have not seen a race to the bottom, but rather a race to the wings with some states failing to use all federal funding available to them and other states providing substantial state funds to supplement the federal CCDF program.

In addition to responding to federal initiatives in highly varying ways, states have also developed their own Pre-Kindergarten (Pre-K) programs. In fact, the bulk of spending on Pre-K comes from state and local governments, not from the federal government. We have information on state expenditures on Pre-K programs that goes back to the 1987-88 school year. In that year, twenty-three states reported spending \$202.6 million on Pre-K programs (Marx \& Seligson, 1988). By the 2001-2002 school year, thirty-seven states reported spending \$2,435 million on Pre-K programs (Barnett, et al., 2003). These numbers for state spending on Pre-K include some flow-through money from federal sources. While we do not know exactly how much flow-through money is included in reported state spending, the federal Department of Education estimated that, in FY2002, approximately \$200 million in federal education spending was spent on PreK programs (http://www.ed.gov/programs/titleiparta/index.html). ${ }^{6}$

Our best estimate is that in FY2002, state and federal spending on early care and education was between $\$ 20$ and $\$ 22$ billion. Approximately 2/3 of this spending came from the federal government. There is also substantial spending on ECE by some local governments (e.g., Palm Beach, Broward \& Miami-Dade Counties in Florida). However, we do not know the total amount of local spending nationwide.

\section{US Early Care \& Education Policy}

As noted earlier, US early care and education policy is highly fragmented in terms of funding, policies, regulations. To understand how this situation emerged, we briefly review the history of federal and state ECE programs.

\footnotetext{
${ }^{6}$ Title 1 of the Elementary and Secondary Education Act (ESEA) provides direct, formula based funds to local schools with large numbers of poor children. In late 2001, only about $30 \%$ of schools used Title 1 funding for Pre-K programs, while $80 \%$ used state or local education funds for this purpose (Smith, et al., 2003).
} 
US governments have only shown sustained interest in early care and education since the 1960s. ${ }^{7}$ As part of the War on Poverty, the federal government established the Head Start program, and state and local governments established Pre-Kindergarten (PreK) programs.

\section{Head Start Programs}

Head Start was designed to provide comprehensive services on a part-day (3 to 6 hours), part-year (generally the school year) basis to three- to five-year-old children living in poverty (i.e., living in families with incomes below the Federal Poverty Level). Head Start has never been funded to serve all eligible children. Even today, it serves less than $40 \%$ of eligible children. Until the Good Start, Grow Smart initiative in 2002, Head Start was seen mainly as a child development program and family intervention program. It provides a wide array of service (e.g., medical and dental screenings) in addition to ECE services.

Traditionally most children in Head Start came from families that were either current or former cash assistance recipients because of Head Start income limits and because Head Start required active parental participation in the program. Consistent with the civil rights movement's distrust of some state governments, Head Start grants were given directly to mainly non-governmental local groups such as anti-poverty programs called Community Action Programs. In 2003 there were 19,200 Head Start Centers, serving 909,608 children with an average cost per child of $\$ 7092$. Of these centers, the majority was community programs, and 115 centers were sponsored by faith-based organizations.

Both welfare reform and the Good Start, Grow Smart initiative of 2002 have caused changes in Head Start. The decline in welfare caseloads after welfare reform meant that Head Start now serves more working families and fewer TANF recipients. In 1997, 45\% of Head Start families were receiving TANF. By 2001 only 24\% of Head Start families were TANF recipients.

The Good Start, Grow Smart initiative seeks a number of changes in Head Start. First, Head Start is to be subject to a new accountability system that will assess every Head Start centers performance in developing literacy, language and numeracy skills. Second, Head Start is being asked to align their activities with State K-12 standards. Finally, Head Start is being asked to upgrade the education and training of its staff.

Major changes in Head Start include the following. First, Head Start is now serving greater numbers of younger children, including infants and toddlers, in the Early Head Start program. In 1997, 61\% of the children in Head Start were four years old. By 2001, only 54\% of Head Start children were four-year-olds. Second, Head Start is now either directly funded or obtaining funding from other sources (mainly CCDF vouchers for wrap-around care) to provide full-day, full-year care to the growing number of working families it serves. In 1997, 38\% of Head Start families needed full-day, full-year child care, while in 2001 49\% of Head Start families required such care. In 1997, 9\% of Head Start families requiring full-day, full-year care received it at Head Start facilities and an additional $4 \%$ of these families received full-day, full-year care using other public subsidies, mainly child care vouchers for wrap-around care. In 2001, $41 \%$ of Head Start

\footnotetext{
${ }^{7}$ During World War II the federal government provided child care for an estimated 550,000 to 600,000 children so that their mothers could work to support the war effort.
} 
families requiring full-day, full-year care received it at Head Start facilities and an additional $13 \%$ of these families received full-day, full-year care at providers other than Head Start using other public subsidies, mainly child care vouchers for wrap-around care. Finally, Head Start teachers have gradually become more educated. In 1997, 34\% of Head Start teachers had an associate degree or higher in ECE or a related field. By 2001, $41 \%$ of Head Start teachers had such degrees.

While basic funding for Head Start comes from the federal government, grantees are expected to provide $20 \%$ matching funds. Eighteen state governments help local groups to meet the federal match requirement. Nine of these states (e.g., Ohio, Minnesota) provide funds above the federal matching requirements to expand the number of children served by Head Start (Education Commission of the States, 2004, Novak, 1999). Individual local organizations apply for funding, and grants are awarded by the Department of Health and Human Services Regional Offices on a three-year basis. Each year, funding is disbursed by the regional offices, but first the federal government allocates money to the states based upon a formula which takes into account the number of children from birth to age four who are living in families with incomes below the poverty line in each state (Currie and Neidell, 2003).

In a recent paper, Currie and Neidell (2003) found that poorer counties (counties with a poverty rate greater than the national median, 11\%) receive lower levels of Head Start funding than richer counties. Since poor counties frequently have large concentration of Black and Hispanic children, on average Black and Hispanic children attend larger and more poorly funded Head Start Programs than white children (Currie and Neidell, 2003).

\section{Pre-K Programs}

While Head Start was a federal creation, Pre-K programs are state and local creations serving mainly disadvantaged four year olds. States like California began Pre-K programs in the mid 1960s, but the major expansion of Pre-K programs occurred in the 1990s. In 1988, 23 states had small Pre-k programs (Marx, and Seligson, 1988). All of these states have expanded their programs, many markedly, since 1988. In addition, 17 states have established Pre-k programs since 1988. Since 1988, states have become more flexible in regards to what types of organizations they will use to distribute money for Pre-k programs. Pre-K programs also have increased the amount of money spent per child. In 1988 the average money spent per child was between $\$ 700$ and $\$ 1000$; today, the average spent per child is between $\$ 3000-\$ 5000$.

States and local areas have created quite distinct program. In eight states (e.g., Louisiana, Pennsylvania and Wisconsin), Pre-K programs are provided only by the publics schools. In seventeen states, funding flows to the public schools, but the school may contract with other entities (e.g., private child care facilities, YWCAs, Head Start programs) to provide Pre-K services. Sixteen states allow organizations other than the public school both to receive Pre-K funding and to provide Pre-K services. One state (Nevada) had all Pre-K services provided by a private entity (Classroom on Wheels of Nevada). Whether publicly or privately provided, the major goal of most Pre-K programs is to prepare poor children for school. While most Pre-K programs are targeted to disadvantaged children, two states (Georgia and Oklahoma) make Pre-K services available to all four year old children. New York is phasing in a universal Pre-K program. 
We have more comprehensive information on school-based Pre-K programs than on programs outside the public schools. By FY 2000-2001, 35\% of public elementary schools offered either half-day or full school-day Pre-K programs. Nineteen percent of schools offered half-day Pre-K (generally 3 hours) and $13 \%$ offered full school-day Pre$\mathrm{K}$ (generally six hours). Three percent of schools offered both half-day and full schoolday programs. See Smith, et al. (2003) for details.

Interestingly, public-school based Pre-K (particularly full-day Pre-K) is far more likely to be available in the Southeast than in other parts of the country. Thirty-six percent of public schools in the Southeast offered full school-day Pre-K programs in FY2000-2001, while only 4\% of public schools offered Pre-K programs in the central area of the country. A similar pattern of availability is found for public kindergarten programs. Eighty-four percent of public schools in the southeast offer full school-day kindergarten, while only $37 \%$ of public schools in the Northeast make full school-day kindergarten available. ${ }^{8}$

States using private entities to provide Pre-K services have widely varying programs. We describe four examples of the programs. Trowbridge and Witte (2004b) provide a description of all Pre-K programs currently operating or planned.

Massachusetts' Pre-K program, the Community Partnerships for Children, is run by local councils. These councils have representatives from the public schools, Head Start, and the CCDF child care voucher program. Funding comes from federal (e.g., TANF transfers), state, and local sources. Services are provided for children ages three to five living in families with incomes up to $125 \%$ of state median income. Preference is given to low-income families on the waiting list for child care vouchers. At least 1/3 of services provided must operate full-day, full-year and participating programs must be accredited.

Georgia offers free pre-kindergarten to all four-year olds in the state through a lottery-funded program administered by an independent state agency (the Office of School Readiness). Participation is voluntary, and slightly less than $60 \%$ of children participate in the program. Funding and policy decisions are made at the state level. Public and private child care and preschool providers are eligible to receive state payments for every enrolled four year old, if they agree to use one of several approved curricula and meet other state standards. Programs are required to operate 6.5 hours a day, five days a week, 180 days of the year.

New Jersey's Early Childhood Program Aid provides funding to 128 districts in which at least $20 \%$ of students are low income. This funding ensures that kindergarten is extended to a full school-day for all five year olds, and half-day preschool is offered to all resident three and four year olds. Services must be offered five days a week for the entire school year. In 1999 about 44,186 children were served in the targeted districts, whose children account for about $40 \%$ of the state's children. Funding decisions for districts are made at the state level, based on a modified K-12 enrollment and poverty level formula. The program is intended to foster collaboration with local child care providers, and public

\footnotetext{
${ }^{8}$ Note the data for kindergarten are for the AY1998-1999. These are the latest data available. See Watson and West (2004).
} 
school districts may provide preschool directly and/or may contract with Head Start, licensed private nonprofit agencies, and licensed child care centers. ${ }^{9}$

The Texas Pre-Kindergarten Program is unique in that it is the only state prekindergarten program that requires a school district to provide a Pre-K program if 15 "educationally disadvantaged" four year olds reside in the district. "Educationally disadvantaged" refers to children whose families are low-income, unable to speak English, or homeless. In 1999, 13,411 three year olds and 125,018 four year olds were served. Funding is done through the Foundation School Program (regular education aid) with each district claiming reimbursement for its Pre-K program based on the average daily attendance of enrolled children. The Pre-K programs can be operated only by school districts and within public school facilities, although subcontracting is permitted. Pre-K programs must meet at least three hours a day for the full school year and be taught by a certified teacher. ${ }^{10}$

\section{CCDF Child Care Subsidy Program}

The federal government established a child care voucher program as part of welfare reform, which began in the late 1980s. The Family Support Act of 1988 provided active AFDC recipients (i.e., those working or engaged in other approved activities such as the JOBS program) and working former recipients during their first year off welfare with an entitlement to child care vouchers for children less than age 13. Child care vouchers were expanded to include low-income families without recent AFDC receipt by the 1990 Omnibus Reconciliation Act. This Act created the At-Risk Child Care Program to provide child care vouchers to low-income families who were at risk of becoming cash assistance recipients. The At-Risk Child Care Program was funded by the Child Care Development Block Grant (CCDBG). CCDBG also provided states with funds to undertake activities to improve the quality and supply of child care for all families. Child care vouchers funded under these and subsequent programs were seen primarily as a support that allowed low-income single parents to work.

Impatient with the pace at which welfare reform proceeded in the early 1990s, Congress passed the Personal Responsibility and Work Opportunity Reconciliation Act (PRWORA) in 1996. This Act changed many social welfare programs, most radically the AFDC program. The Act also called for dramatic changes in the child care voucher program. The funding stream for vouchers was renamed the Child Care Development Fund (CCDF). ${ }^{11}$ The program was seen as an important element in allowing cash assistance recipients to achieve financial independence. Funding for child care vouchers was increased dramatically and consolidated into a single block grant to the states. The entitlement to child care under the Family Support Act was abolished and states were given substantial latitude to develop programs that best suited their particular circumstances.

Because of the substantial changes in the economic and political milieu from the 1960 s to the late 1980 s, the child care subsidy program developed very differently than

\footnotetext{
${ }^{9}$ See http://www.state.nj.us/njded/genfo/toc.htm for more information regarding pre-kindergarten programs in New Jersey.

${ }^{10} \mathrm{See}$ http://www.tea.state.tx.us/curriculum/ece.html for further information.

${ }^{11}$ Although vouchers are now said to be funded by Care Development Fund, the block grant to the states is still called the Child Care Development Block Grant.
} 
the Head Start that began in the 1960s. While direct federal grants to provide services were central to the Head Start, the federal child care subsidy program is a block grant to states mainly to provide child care vouchers. Under the child care subsidy program, parents are given vouchers that they can use to purchase ECE from licensed formal providers (e.g., centers and family child care homes) or from informal sources (e.g., family and friends) that can pass minimal screening requirements (e.g., criminal record checks). Most vouchers are used to purchase formal care. For example, in FY2000, 74\% of children receiving child care vouchers were cared for in regulated settings (i.e., centers and family child care homes), with $58 \%$ being cared for in child care centers (Child Care Bureau, 2003).

Child care centers in the US are overwhelmingly run by non-governmental entities. These entities have differing goals, different funding sources and often run quite different types of programs. In 1990, the latest period for which national data are available, about $10 \%$ of child care centers were public, and $90 \%$ were private. Of the private centers, two thirds were nonprofit and one third was for profit. Among the nonprofit centers, $25 \%$ were independent nonprofits, $15 \%$ were sponsored by a religious organization, $8 \%$ were run by large nonprofit organizations (e.g., the YWCA), $8 \%$ were public schools and 9\% were Head Start providers. Within the for-profit sector, $6 \%$ of centers were part of child care chains and $29 \%$ were independent entities (Willer, Hofferth \& Kisker, 1991). Family day care is almost all private (OECD, 2004b).

Beginning in the late 1990s, state child care voucher programs began to evolve quite differently. During the early years of $\mathrm{CCDF}$, states tended to retain separate child care voucher programs for current and former cash assistance recipients and other lowincome families. Even today many states give priority for child care vouchers to active cash assistance recipients and to former cash assistance recipients during their first year off cash assistance (e.g., Florida, Massachusetts). Other low-income families are placed on waiting lists for child care vouchers. By way of contrast other states provide vouchers to all eligible applicants and have consolidated their child care voucher program for current and former cash assistance recipients and other low-income families (e.g., Illinois, Rhode Island). States also vary widely in both the level and definition of income used to determine eligibility, the level of parental co-payments, the proportion of providers that accept child care vouchers and the type of care purchased with vouchers. Some states have devolved most policy making and administration of the voucher programs to local governments (e.g., Florida, Texas) while other states retain state-run programs (e.g., Illinois and Massachusetts). See Loprest, et al. (2000) for a more detailed description of the operation of the CCDF block grant and Collins, et al., (2000) for a more detailed examination of differences across state programs.

\section{Public Funding for US Early Care and Education}

While federal government funding for early care and education has come from general revenue, state and local governments have used a wide array of revenue raising and revenue enhancing methods to increase funding for early care and education. The methods include taxes, fees, lotteries and gaming, and partnering with the private sector, philanthropy or local community groups. We will describe, in turn, important examples of each of these methods of increasing funding for early care and education. Mitchell, et al. (2001) provides a detailed account of financing methods. 


\section{Taxes}

States have used general revenue, income tax check offs, sales tax revenue and excise tax revenue to increase funding for early care and education. The vast majority of states use general revenue to provide Pre-K services. Typically, states put a separate line item in the budget for Pre-K, have Pre-K as a line item in the education budget or embed Pre-K in the state education aid formula. Some states such as Rhode Island substantially supplement federal CCDF child care voucher funds with state general revenue. Many other states (e.g., Minnesota, Ohio) substantially supplement federal Head Start funding with general revenue.

State taxation earmarked for early care and education is used frequently, with sin taxes being particularly popular sources of earmarked revenue. Two states (Arkansas and South Carolina) have increased state sales taxes to fund Pre-K programs. Arkansas placed a surtax on beer to fund preschool and California passed Proposition 10, which placed a tax on tobacco to fund universal Pre-K in a number of counties.

Local governments also have raised taxes to support early care and education. For example, Florida allows counties to set up children services districts to fund programs for children of all ages. In ten Florida Counties the children services districts are funded by the general revenue of the county, while districts in eight counties (Broward, Hillsborough, Martin, Miami-Dade, Okeechobee, Palm Beach, Pinellas and St. Lucie) have independent taxing authority. The districts with independent taxing authority typically levy an add-on to the property tax. For example, Pinellas County levies $\$ 1$ per $\$ 1000$ of assessed valuation for children's programs, and Palm Beach County levies \$.47 per $\$ 1000$ of assessed valuation.

\section{Fees}

A number of states and municipalities have fees that are used for child care. Some fees are imposed and others are voluntary. Whether imposed or voluntary, fees have not been a major source of revenue for child care. For example, Santa Cruz, CA Child Care Developer Fee Loan Program requires that new developments make payments to offset the increase in child care costs that they impose on the County. These funds are used to provide loans or grants to child care providers. However, the annual loan volume is generally less than $\$ 100,000$. Kentucky allows any person registering or reregistering their vehicle to donate $\$ 1$ to the Motor Vehicle Child Care Assistance Account. This account is used to provide child care assistance to low-income families that have incomes just exceeding the limit for CCDF child care subsidies. Donations have not exceeded $\$ 50,000$ and are usually far less.

\section{Lotteries and Gaming}

The "voluntary" taxes associated with gambling have been an important source of state child care funding for some states. For example, Georgia funds its voluntary, universal Pre-K program with lottery dollars (\$224 million in FY2000). Missouri funds its Early Childhood Development, Education and Care Fund (ECDEC) with riverboat gambling fees. ECDEC fund appropriations were approximately \$21 million in FY 19992000 . 


\section{Public Partnerships}

The most successful examples of the public sector partnering with private sector organizations, including for-profit employers, have occurred in the southeast. We will highlight two quite different programs, one in North Carolina and one in Florida.

North Carolina (NC) has had by far the most successful public-private partnerships for early care and education. Two successful public-private partnerships for early care and education, Smart Start and T.E.A.C.H, have operated in North Carolina since the early 1990s. With support from national foundations, North Carolina's Smart Start and T.E.A.C.H programs have expanded to many other states. ${ }^{12}$

\section{Smart Start}

Smart Start, passed by the NC Legislature in 1993, is a comprehensive initiative to make early care and education services available to all children under age 6 whose families need and want such services. An amendment passed in 1995 required that the local, private, not-for-profit boards that administer Smart Start raise a 10\% match for state funding. At least half of the matching funds must be in cash, not in kind.

State funding for Smart Start was \$192 million in state FY2004. The state and local Smart Start programs raised over $\$ 200$ million from the private sector since its founding. 13

\section{Child Care Partnerships}

Florida passed the Child Care Partnership Act as part of its 1996 welfare reform. The Act was designed to encourage businesses to pay a portion of the cost of child care for their employees who earn low wages. The Act created a nine-member Executive Partnership composed of corporate leaders that established specific guidelines and eligibility criteria for the program.

Under the Partnership, the state matches $\$ 1$ for $\$ 1$ employer contributions to provide child care vouchers for their low-income employees. The combined state and employer funds are placed in a purchasing pool administered by the same local child care agency that administers child care voucher program. Employees earning less than 200\% of the FPL are eligible to use funds from the pool.

During the first year of the program, the state contributed $\$ 2$ million to purchasing pools. In FY 2003-2004, the state contributed \$19 million.

A study documenting which companies employed large numbers of child care voucher recipients helped martial business support for the Child Care Partnership Act (Lee, Ohlandt \& Witte, 1996). The study has been replicated in a number of other states and the District of Columbia; however, to date, no other state has passed a bill comparable to Florida's Child Care Partnership Act. ${ }^{14}$

This might suggest that there is limited opportunity to have employers directly bear some of the child care costs of their employees. However, in the Netherlands,

\footnotetext{
${ }^{12}$ See http://www.smartstart-nc.org/national/states.htm for a list of states and communities implementing Smart Start and http://www.childcareservices.org/TEACH/T.E.A.C.H.-TACenter.htm for a list of states implementing T.E.A.C.H.

${ }^{13} \mathrm{See} \mathrm{http://www.smartstart-nc.org/overview/donors.htm} \mathrm{for} \mathrm{a} \mathrm{list} \mathrm{of} \mathrm{donors.}$

${ }^{14}$ See http://www.hhs.oregonstate.edu/familypolicy/occrp/publications/2001-Parents-Receiving-ChildCareSubsidies.pdf for a description of the studies carried out.
} 
employers have for many years borne approximately $1 / 3$ of the costs of child care for their employees.

\section{Major Issues for US Early Care and Education}

As should be clear from the write up above, the current early care and education system in the US has grown by increment. Today's "system" is a hodgepodge of different federal, state and local programs. In this section, we will consider: (1) the goals and structure of US early care and education programs, (2) the costs of having three distinct ECE programs, (3) consolidation or coordination of different programs, (3) equality of access and (4) the effectiveness of early care and education programs.

\section{Goals of Early Care and Education}

Unlike early care and education (ECE) in Western European countries, US ECE is neither a cohesive system nor universal, even for disadvantaged children. US ECE is a conglomeration of programs established across the last 40 years with different funding sources, different standards, different structures and, until recently, different goals. Expenditure programs established during the 1960s (e.g., Head Start and Pre-K established prior to the 1990s) were targeted at low-income children. These programs focused mainly on the child. Head Start sought comprehensive child development, while Pre-K generally sought to prepare disadvantaged children for school.

Programs established in connection with the reform of welfare in the 1980s and 1990s provided child care subsidies so that poor, single parents could work. They were seen primarily as work supports and were focused more on the parents than on the children.

In the mid to late 1990s, three states (Georgia, New York and Oklahoma) established universal Pre-K programs to prepare children for school and to further the testing goals of the elementary and secondary schools reform movement. These programs come closer to the European model, but services are only available during the school day for a single year, while cohesive European programs are often available all day for three years.

We will consider and provide information on two major issues regarding the goals of early care and education that governments have addressed. First, will US early care and education be targeted or will it be universal? Second, what relative weight will US governments place on child development, school readiness and providing child care so that parents can work?

\section{Targeted versus Universal Early Care and Education}

Today most US early care and education funding is targeted rather than universal. Georgia and Oklahoma currently offer universal access to one year Pre-K programs and New York is phasing in a one-year universal Pre-K program. There is strong advocacy for universal Pre-K programs in a number of other states. In Florida, this advocacy led to the passage of a constitutional amendment in 2000 that states:

Every four-year-old child in Florida shall be provided by the State with a high quality pre-kindergarten learning opportunity in the form of an early childhood development and education program which shall be voluntary, high quality, free and delivered according to professionally accepted standards. 
The Florida Legislature hurriedly passed a bill "implementing" this amendment during its 2003-2004 session. The bill seems to have pleased no one and makes no provisions for funding the programs established. The bill calls for a three-hour-a-day program beginning in September 2005 that has minimal quality requirements. Since Florida's overcrowded elementary schools have no room to house the new program, services are to be provided by child care centers that currently serve children with child care vouchers. These centers are of markedly varying quality. The bill asked the Governor to figure out how to fund the programs and report back to the Legislature. The Governor vetoed the bill.

The situation in Florida points out the major difficulty in establishing high quality, universal Pre-K programs. High quality, universal programs are very expensive and, as the National Governor's Association and the National Association of State Budget Officers have pointed out, state finances remain "fragile", even in a recovering economy (National Governors Association and National Association of State Budget Offices, 2004).

Further, the push for universal Pre-K has not come to grips with the fact that many states do not have universal kindergarten. Only nine states (Alabama, Arkansas, Georgia, Louisiana, Maryland, Mississippi, North Carolina, South Carolina and West Virginia) currently require that districts offer full school-day (generally six hours) kindergarten (Education Commission of the States, 2003). Nine states (Alaska, Colorado, Idaho, New Hampshire, New Jersey, New York, North Dakota, Pennsylvania and Washington) do not require that school districts offer any kindergarten. Total enrollment in kindergarten peaked in 1992 at 4 million and declined to 3.7 million in 2001; correspondingly, the percent of four to six year olds in kindergarten has declined from $35.4 \%$ in 1992 to $31.2 \%$ in 2001 (Wirt, et al., 2004).

Work Support, Child Development and School Readiness

Both the European and US literature agree that the goal of early care and education programs should encompass: (1) providing work supports for parents, (2) providing situations conducive to the cognitive, social-emotional and physical development of children and (3) preparing children to enter elementary school (Boocock, 1995; Bowman, et al., 2000). While a number of cohesive European programs achieve all three of these goals, the US has established separate programs to concentrate on child development and school readiness (Head Start and Pre-K), and to provide child care while parents work (the child care voucher program).

In his 2002 State of the Union address, President Bush highlighted the importance of ECE to his education reform plan, No Child Left Behind. Under his Good Start, Grow Smart initiative, Head Start was asked to concentrate on preparing children to read and succeed in school. Head Start is to be evaluated on how well they achieved these goals. States were asked to try to better coordinate ECE programs. The initiative did not speak to the need to provide care while low-income parents work.

\section{Costs of Multiple Programs}

The separately operating Head Start, Pre-K and child care voucher program are administratively costly, impose high transaction costs on parents (e.g., each program has its own eligibility requirements and application procedures) and fail to provide stable 
early care and education for children. While there has been much discussion of the high administrative costs and high transaction costs of the current US ECE system, there has been less discussion of the implications of the systems for the stability of care received by children.

Consider a not unlikely scenario for a new single mother who receives cash assistance under the Transitional Aid to Needy Families (TANF) program in Florida. In order to continue to receive TANF benefits, the mother must go to work or participates in other approved activities when her child is three months old. She uses a child care voucher to help her pay for center care of her three-month-old child. The job, the voucher and the child care arrangement last six to nine months. The mother returns to work when her child is twelve months old. Her earnings make her ineligible for TANF. She has a child care voucher for a year and places her one-year old in center care. The center, like most centers in the US, has a 40 percent annual turnover rate for staff; so, the child may well have more than one caregiver during the year. Further, the child's caregiver is likely to have limited education or experience in ECE. The mother continues to work, but loses her child care voucher. She pays a neighbor to take care of her two-year old while she works. After a year, the neighbor moves and the mother places her now three-year-old child in a family child care home. When the child turns four, she is eligible for Pre-K. The Pre-K program will operate either three or six hours per day. The mother enrolls the child in Pre-K and has a neighbor pick up the child after Pre-K ends. When the child is five, she goes to kindergarten at the local public school for six hours per day. A different neighbor picks the child up at the end of the kindergarten day. By the time the child enters elementary school, the child will have had nine different care settings and perhaps twelve or thirteen different caregivers. She will have had two years of part-day, part-year early care and education.

Contrast this with a not unlikely scenario in a Western European country. The new, single mother will receive a ten-month paid, parental leave after the birth of her child. She will have the choice of receiving payments until the child is three and staying home or placing her child in a government provided early care and education program. The child will transfer to the ECE education system when she is three and will remain in the system until she goes to elementary school. By the time the child enters elementary school, the child will have had two or three different care settings and probably less than six different care givers. She will have had at least three years of full-day, full-year early care and education.

\section{Consolidation or Coordination}

Since at least the mid 1990s, Federal, state and local governments have made attempts to coordinate early care and education programs, rather than push for consolidation of ECE. However, most efforts at coordination have come recently, particularly in connections with the recent recession. Unfortunately, these efforts have not been successful by and large, with existing programs often spending more energy protecting their own turf than coordinating their activities. See Groginsky (2002) and Schumacher, et al. (2001) for details.

In its 2001 survey of the states, the National Conference of State Legislatures found that 21 states required a state entity to facilitate coordination or collaboration among programs, agencies, policies or funding for early care and education (Groginsky, 
2002). The Center for Law and Social Policy chose to highlight the coordination efforts of three states (Georgia, Massachusetts and Ohio). While we cannot speak authoritatively about the coordination efforts of Georgia and Ohio, we can speak about coordination efforts in Massachusetts.

Massachusetts is more successful in using CCDF vouchers to provide "wraparound" care for children in Head Start programs than many other states. The wraparound care provides care after the Head Start program ends and allows the combined CCDF voucher and Head Start program to provide support to parents that work full time.

The Commonwealth also requires that at least $1 / 3$ of the children in its Pre-K program - the Community Partnership for Children (CPC) - receive full-day, full-year services. This is a far higher proportion of full-day, full-year care than is available in most state Pre-K programs. For example, Georgia's Pre-K program only requires a minimum duration of 6.5 hours for a five day week, 180 days a year. It sets no requirement for full-day, full-year care.

In spite of being in the forefront of coordination efforts, the Massachusetts legislature was sufficiently dissatisfied with the level of coordination in the Commonwealth that it set up the Council on Early Care and Education in 2003 to report back to the legislature on how to improve coordination of early care and education programs. The Council, run by the state Department of Education (the CPC program), the Department of Health (early intervention services) and the Office of Child Care Services (CCDF funded child care vouchers), released its report in March 2004 (Department of Education, Department of Public Health and Office of Child Care Services, 2004). The report called for "bold action to coordinate services and resources, streamline administrative procedures, and reduce fragmentation in Massachusetts' early education and care policies and programs" (Department of Education, Department of Public Health and Office of Child Care Services, 2004, cover letter). The report provides many examples of the lack of coordination (e.g., different payments to providers for care under CCDF program and the CPC program, different application procedures, different sets of performance standards). At a number of points, the report talks about the need to coordinate efforts with Head Start. However, given the current structure of Head Start, neither the Commonwealth nor any other state is in a position to require Head Start programs to coordinate with state Pre-K programs or with the CCDF subsidy program.

In a recent paper, Edie, et al. (2004) describe seven possible models for a coordinated US early care and education system. The models are: (1) an expanded Head Start model, (2) a Pre-Kindergarten collaboration model, (3) a "School of the $21^{\text {st }}$ Century" Model, (4) a system based on the military model, (5) a "Smart Start" model, (6) an enhanced CCDF child care voucher model and (7) a "Ready to Teach" model. We briefly describe the Schools of the $21^{\text {st }}$ Century model and the Military model here since they are not broadly known.

The Schools of the $21^{\text {st }}$ Century model would use the public schools as a base to provide year around early care and education services for children ages three to five and after-school and vacation care for children ages five to 12 (Zigler, Finn-Stevenson \& Marsland, 1995). While this model is comprehensive and could provide more stable care settings, it builds on the public schools, which have seen increasing criticism. However, 
this model does have some evidence of short-term effectiveness in preparing children for school and providing work supports for parents. ${ }^{15}$

The Military Model is based on the early care and education program developed by the US military. Except for personnel matters and funding, the military system operates somewhat like the child care voucher program. Military families needing child care receive vouchers and go to a resource and referral agency which provides information on the child care options available (centers, family child care homes, beforeand after-school programs). The military rigorously enforces minimum standards in its 800 centers and 9000 family child care homes operated by military spouses or family members. The military provides half of all ECE costs directly with the other half of costs being split between the military and low-income military families. Ongoing training is required of all teachers/caregivers. There is a well defined career ladder with increased compensation upon completion of each level of training and evidence of demonstrated competence.

\section{Equality of Access}

The US system of early care and education does not provide access to early care and education that is either horizontally or vertically equitable. As far as vertical equity is concerned, the OECD estimates that only $45 \%$ of three- to five-year-old children in the US living in low-income families are enrolled in preschool, while $75 \%$ of three to five year olds in higher income families are enrolled (OECD, 2004b).

Due to poor coordination and under funding, ECE programs for low-income children are also horizontally inequitable. Subsidized care opportunities for children less than four are generally limited to child care vouchers. Four year olds living in families with incomes below the FPL are eligible for Head Start, Pre-K and child care vouchers. However, because almost all of these programs are under-funded, only some of these children will actually receive subsidized ECE.

Fewer than one in four children eligible for CCDF vouchers will actually receive vouchers. Parents that receive vouchers will pay anywhere from $\$ 0$ to $10 \%-20 \%$ of their gross income for the CCDF subsidized care. Caregivers are likely to have limited education and ECE experience.

Less than $40 \%$ of eligible four year old children will receive comprehensive services (including health and dental care) from Head Start for part of the day, part of the year. The parents of these children will pay nothing for the services their children receive. Head Start caregivers are likely to have a Child Development Associate (CDA) credential, which generally requires about a year of post high school education, or and A.A. degree.

Other four year olds will be in Pre-K programs that run from 3 to 6 hours a day. The programs will often be staffed by qualified teachers and will aim to prepare the children for school. The parents will pay nothing for the Pre-K program.

${ }^{15}$ See www.yale.edu/bushcenter/21C/research.html. 


\section{Effectiveness of Early Care \& Education Programs}

The major ECE programs in the US have rarely been subjected to rigorous evaluation. When Head Start was last reauthorized in 1998, Congress ordered a randomassignment evaluation of the impacts of Head Start. The results of this evaluation are not yet available.

The existing literature on Head Start is mixed. In some situations and for some students, Head Start has significantly positive effects at least in the short term. Head Start's part-day, part year program costs approximately $\$ 7,000$ per child. See Haskin and Sawhill (2003) for a recent survey of the Head Start literature or Schweinhart (2001) for a somewhat older but more detailed survey.

The evaluation research on the impacts of Pre-K programs is more limited than the research on Head Start. Gilliam and Zigler (2000) provide a thorough survey of the literature through 1998 and Schweinhart (2001) provides a briefer review of the literature through 2000. Gilliam and Zigler conclude that the evaluations of Pre-K programs provide modest support for positive program effects on children's developmental performance, school performance and attendance, and reduced percentages of children held back a grade.

More recently Gormley \& Gayer (2003) provide a strong quasi-experimental evaluation of Oklahoma's universal Pre-K program and Henry, et al. (2003) provide a comprehensive evaluation of Georgia's Pre-K program. Both evaluations provide evidence of significant positive effects through the beginning of kindergarten. These two evaluations are quite different. While the Oklahoma study compares results for students who attended Pre-K with those who did not, the Georgia study compares the results for children that attended its Pre-K program with results for children that attended Head Start and for children that attended private preschool. The Georgia study finds that the Georgia Pre-K program more effectively prepared children for school than either Head Start or private preschools. The study attributes Pre-K's better results to better teacher quality, a strong focus on preparing children for school and frequent feedback and monitoring. The Georgia study also finds substantial learning loss in the period between Pre-K and kindergarten, particularly for Afro-American children.

A recent paper (Magnuson, et al., 2004), uses data from the Early Childhood Longitudinal Study and finds that typical Pre-K programs increase reading and mathematics skills at school entry, but they reduce self control and increase behavioral problems. The positive effects on skills dissipate by the end of the first grade, but the behavioral problems continue. The largest and most lasting effects are found for disadvantaged children and for those attending schools with low levels of academic instruction.

Child care vouchers have been around for a shorter period of time than either PreK or Head Start. Further, the programs vary substantially not only across states but within states. See Child Care Bureau (2003) for details. The majority of care is provided in child care centers (57\% in FY2000) or family child care homes (29\%). The majority of care is full-time ( 8 to 10 hours per day), but the average duration of care is short, generally less than six months (Myers, et al., 2002). Annual expenditure per child served in 1999 ranged from \$2321 in Virginia to \$5913 in Minnesota (Witte and Queralt, 2002).

To date there have been few evaluations of the impacts of CCDF vouchers. Further, until recently child care vouchers were seen primarily as a work support and, 
consequently, existing evaluations tend to assess impacts on parental work or welfare receipt rather than child outcomes. Witte and Queralt (2003) find that the combined effect of Rhode Island's reform of its cash assistance and child care voucher programs was to almost triple the probability that current and former cash assistance recipients would work 20 or more hours per week and approximately to cut in half the probability that a single mother would be on cash assistance and neither working nor in some other approved activity. The impact of North Carolina's Smart Start program, a state-enhanced version of CCDF subsidies, on children has been evaluated using a quasi-experimental design. The latest report (Bryant, et al., 2003) indicates that Smart Start significantly improved the quality of child care providers. Further, the report indicates that children in higher quality centers scored significantly higher on measures of skills and abilities deemed important for success in kindergarten than children from lower-quality centers.

In 2001, the Child Care Bureau funded a project to evaluate the impacts of different child care voucher strategies, using four random assignment experiments. To date, only one experiment is underway. This experiment is testing the impact on school readiness of using different curricula for subsidized children in child care centers. The experiment is being carried out in Miami-Dade County, Florida. Preliminary results of the project should be available in 2005 . $^{16}$

The overall conclusion of the literature is that the large scale ECE programs in the US have had, at best, short term positive impacts on the children that participated in the programs. However, rigorous evaluations of smaller scale, more intensive and more expensive programs show more positive and longer term impacts. See Table 6 of Carneiro and Heckman (2003) for descriptions of the programs. The two most cited of these studies are the experimental evaluations of the High Scope/Perry Preschool program and the Carolina Abecedarian program. We will briefly describe and assess the results of these evaluations.

The High Scope/Perry Preschool program operated from 1962 until 1967 in Ypsilanti Michigan. The program provided weekly home visits with parents and intensive, high quality preschool services for one to two years to low-income children with average IQs of 80 . The program was evaluated using a random assignment experiment that followed participants through age 27. For almost three decades, the study followed the lives of 123 children from African American families who lived in the neighborhood of the Perry Elementary School in Ypsilanti, Michigan from 1962-1967. The median percentage of missing cases in each year that the survey was administered was only $4.9 \%$ (Schweinhart, Barnes \& Weikart, 1993). The internal validity of this study isn't questioned, but our ability to make generalizations outside of the experimental group is limited due to the small sample size and the non-random nature of the sample.

In 1990 dollars, the average cost per child of the High Scope program was $\$ 13,400$ (\$15,844 in \$2002). Evaluation results indicate that the experimental group had significantly fewer special education placements and significantly higher graduation rates than the control group. Further, experimental group members had significantly higher earnings, higher percentages of home ownership and second car ownership at age 27, higher levels of schooling completed, lower percentages receiving social services at some time in the previous 10 years, and lower arrest rates than control group members.

\footnotetext{
${ }^{16}$ See http://www.mdrc.org/project_16 38.html for a brief description of the project.
} 
Measured through age 27 , the program returned $\$ 5.70$ for every dollar spent. A substantial fraction $(65 \%)$ of the returns to the program is attributable to reductions in criminal activity. The experimental group averaged significantly fewer lifetime arrests (2.3 v. 4.6) and significantly fewer undropped misdemeanor cases, and fewer months on probation or parole. Such large scale criminal justice impacts can only be expected in high crime areas like the area served by the Perry Preschool. Recently, Rolnick (2004) has estimated that the average real rate of return to the project was $4 \%$ to the individuals involved and $12 \%$ to the public. See Schweinhart, Barnes \& Weikart (1993) for details about the program.

The Carolina Abecedarian program operated from 1972 to 1985 in Chapel Hill, North Carolina. The program provided intensive full-day, year-round services to children from infancy to five years of age in low-income families. The program was evaluated using a random assignment experiment that followed 112 participants, mostly of AfroAmerican descent, through age 21. In 2002 dollars, the average cost per child of the experiment was $\$ 67,225$. The experimental group had significantly higher IQs than the control group through age 12. Significant increases in reading and mathematics scores continued until age 21 . The experimental group also was significantly less likely to be retained in grades or to receive special education placement than the control group. Further, experimental group members were significantly more likely to attend college by age 21 than were control group members (36\% of experimental group members attended college v. $13 \%$ of control group members). The program did not have a significant impact on number of arrests, possible because Chapel Hill is not a high crime area.

Mass and Barnett (2002) have carried out a benefit-cost analysis of the Abecedarian program. Their analysis estimates most benefits, given that many things such as earnings of participants were not followed. They conclude that overall, including all estimated benefits, the return to the program is no less than $3 \%$ and may be higher than $7 \%$. They also estimate that the return to the public (excluding participants) is $-3 \%$. That is, most of the gains from the program accrue to program participants.

Taken as a whole, the US evaluation literature provides some support for intensive preschool programs (i.e., programs lasting two years or more that are full-day and full year) providing significant, long term net benefits.

\section{Evaluations of European ECE Programs}

Evaluations of European ECE programs rely on random assignment experiments much less than US evaluations, possibly because European ECE tends to be universal and random assignment raises ethical issues. Overall, evaluations of high quality, well integrated, universal European ECE programs conclude: (1) there is no strong or consistent evidence that the form (pedagogic approach, daily schedule, or setting) of universal, high quality, stable programs influences long-term outcomes for children, (2) ECE programs have stronger effects on more disadvantaged students, (3) European-style ECE programs can narrow the achievement gaps faced by disadvantaged children, though most of these effects tend to diminish over time and (4) maternal employment and out of home care in universal, high quality, stable, full-day, full-year programs after the first year appear to yield benefits to both the child and the mother. See Boobock (1995), Waldfogel (2001) and Groot, et al. (2004) for details.

\section{Evidence from Canada}

Cleveland and Krashinsky (1998) make a convincing case that in Canada a comprehensive public program, providing relatively high quality, licensed, full-day, full- 
year child care to all children aged two to five years with working parents and enriched nursery school for children cared for by their parents at home can provide benefits approximately twice the costs. The system that Cleveland and Krashinsky evaluate costs approximately $\$ 8500$ (1998 Canadian \$) for full-day, full-year care. Under the system, caregivers would be paid about $\$ 30,000$ and fringe benefits would add $20 \%$ to costs; so, the total cost per caregiver would be $\$ 36,000$. This amount far exceeds the average pay of the typical child care worker in the US, but it is substantially less then the pay of the typical public school teacher. In carrying out their analysis, Cleveland and Krashinsky estimate both static and dynamic benefits for parents and children.

\section{Conclusions}

Recent economic research suggests that there is a high return to early care and education (ECE) and a much lower return to compensatory interventions later in the lifecycle. This research also highlights the importance of both cognitive and non-cognitive skills that are formed early in the life cycle for educational achievement, earnings and other dimensions of socioeconomic success (Carneiro \& Heckman, 2003).

Most European governments have universal, consolidated, education-based ECE programs that are available from early in the morning to late in the evening throughout the year. European ECE programs are uniformly of high quality, generally last at least three years, and are funded to serve all children. European programs yield benefits to both the mother and the child. They also narrow the achievement gap faced by disadvantaged children, though most of these effects tend to diminish over time.

The US ECE system is composed of three separate programs (Head Start, PreKindergarten and the child care voucher program) targeted to low-income children. With a few notable exceptions, US ECE programs are funded to serve less than half of the eligible children. US ECE programs developed quite separately. They have different goals, different funding sources, different administrations and policies, and generally last for an academic year or less. Pre-K and Head Start operate only 3 to 6 hours a day and are open only during the academic year. The average quality of US ECE programs is generally much lower than the average quality of European ECE programs. Further, the quality of US ECE programs varies widely even within local areas. Although the US has greatly increased expenditures on ECE, US governments pay only $40 \%$ of the costs of ECE, while European governments pay $70 \%$ to $90 \%$ of the costs of ECE. None of the major US ECE programs simultaneously provides work supports for parents, child development opportunities for children, and low-income children with the cognitive and non-cognitive skills needed for success in school.

The evidence suggests that the US ECE system is neither efficient nor equitable. Consolidation of funding and administration of current US ECE programs could substantially lower transaction costs for parents and provide more stable care arrangements for children. Increased funding could improve the quality of existing programs, extend hours and months of operation, and make care available to all eligible families. Both the evaluation literature and the European experience suggest that such a consolidated, well-funded system could be successful in preparing poor children for school. Further, the benefits of such a program could well exceed the costs since it is precisely low-income children that benefit most from stable, high-quality ECE. However, such a targeted program will have neither the positive peer group effects nor the social- 
integration benefits of universal ECE programs. Further, and perhaps more importantly, targeted programs are likely to have less broad-based popular support than universal programs. 


\section{References}

Administration for Children and Families. (2003). TANF Financial Data. Available at: http://www.acf.hhs.gov/programs/ofs/data/index.html. Accessed: 6/04.

Altshuler, R. \& Schwartz, A. (1996). On The Progressivity Of The Child Care Tax Credit: Snapshot versus Time-exposure Incidence, National Tax Journal, 49, 55-71.

Barnett, S., Bobin, K., Hustedt, T. \& Schulman, K. (2003). The State of Preschool. Rutgers, NJ: National Institute for Early Education Research.

Boocock, S. (1995). Early Childhood Programs In Other Nations: Goals And Outcomes, The Future of Children, 5, 94-114.

Bowman, B., Donovan, M. \& Burns, M. (eds.). 2000. Eager to Learn: Educating Our Preschoolers. Washington, DC: National Academy Press.

Bryant, D., Maxwell, K, Taylor, K, Poe, M., Peisner-Feinberg, E. and Bernier, K. (2003). Smart Start and Preschool Child Care Quality in NC: Change over Time and Relation to Children's Readiness.

Bureau of Economic and Business Affairs. (2001). Norway; Key Economic Indicators. Available at: http://www.state.gov/documents/organization/1627.pdf. Accessed: $7 / 15 / 04$.

Carneiro, P \& Heckman, J. (2003). Human Capital Policy. NBER working paper 9495. Available at www.nber.org/papers/w9495. Accessed 7/1/2004.

Child Care Bureau. (2003). Child Care and Development Fund Report to Congress. Washington, DC: Administration for Children and Families, US Department of Health and Human Services.

Children's Defense Fund. (1999). Seeds of Success: State Pre-K Initiative 1999-1999. Washington, DC: Children's Defense Fund.

CIA. (2000). World Factbook. Available at:

http://luna.wellesley.edu/search/XCIA+world+factbook\&submit=SUBMIT\&l=\&b=\&m= $\& \mathrm{SORT}=\mathrm{D} \& \mathrm{p}=\& \mathrm{Da}=\& \mathrm{Db}=/ \mathrm{XCIA}+$ world + factbook $\&$ submit $=$ SUBMIT $\& \mathrm{l}=\& \mathrm{~b}=\& \mathrm{~m}=\& \mathrm{~S}$ ORT $=\mathrm{D} \& \mathrm{p}=\& \mathrm{Da}=\& \mathrm{Db}=/ 1,25841,25841, \mathrm{~B} / 1856 \& \mathrm{FF}=\mathrm{XCIA}+$ world + factbook $\& 2,2,1,0$. Accessed: 7/15/04.

Clearinghouse on International Developments in Child, Youth and Family Policies. (2002). Mother's Day: More Than Candy And Flowers, Working Parents Need Paid Time-Off, Issue Brief, Spring. Available at: http://www.childpolicyintl.org/. Accessed: $8 / 04$. 
Clearinghouse on International Developments in Child, Youth and Family Policies. (2002). Tax Day: How Do America's Child Benefits Compare?, Issue Brief, Spring. Available at: http://www.childpolicyintl.org/. Accessed: 8/04.

Clearinghouse on International Developments in Child, Youth and Family Policies. (2004a). Table 1.22: Early Childhood Education and Care Policy Dimensions and Programs in Selected Countries. Available at: http://www.childpolicyintl.org/.

Accessed:8/25.

Clearinghouse on International Developments in Child, Youth and Family Policies. (2004b). Table 1.23: Main Institutional Day Care for Children in 8 European Nations. Available at: http://www.childpolicyintl.org/. Accessed: 8/25.

Cleveland, G. \& Krashinsky, M. (1998). The Benefits and Costs of Good Child Care. Toronto: Childcare Resource and Research Unit, University of Toronto.

Collins, A., et al. (2000). National Study of Child Care for Low-Income Families: State and Community Substudy Interim Report. Cambridge, MA: Abt Associates.

Committee for Economic Development. (2002). Preschool for All. New York: Committee for Economic Development.

Committee on Ways and Means. (2000). Green Book. Available at: http://aspe.hhs.gov/2000gb/. Accessed: 6/04.

Currie, Janet and Neidell, Matthew. (2003). Getting Inside the "Black Box" of Head Start Quality: What Matters and What Doesn't? NBER working paper 10091. Available at http://www.nber.org/w10091. Accessed on 6/24/04.

Department of Education, Department of Public Health and Office of Child Care Services. (2004). Report of the Massachusetts Early Education and Care Council. Boston: Department of Education, Department of Public Health and Office of Child Care Services.

Digest of Education and Statistics. (1996). Average undergraduate tuition and fees and room and board rates paid by students in institutions of higher education, by type and control of institution: 1964-65 to 1995-96. Available at: http://nces.ed.gov/programs/digest/d96/D96T309.asp. Accessed on 6/04.

Edie, D. , Adams, D., Riley, D. \& Roach, M. (2004). Alternative Models for an Early Care and Education System. Madison, WI: Wisconsin Child Care Research Partnership.

Education Commission of the States. (2004). Pre-kindergarten. Available at: http://www.ecs.org/ecsmain.asp?page=/html/IssuesEL.asp. Accessed 6/2/04. 
Foner, E. \& Garraty, J. (1991). The Readers Companion to American History. New York: Houghton Mifflin. Available at:

http://college.hmco.com/history/readerscomp/rcah/html/ah_027603_iiihigheredu.htm.

Accessed May 31, 2004.

Gilliam, W. \& Zigler, E. (2000). A Critical Meta-Analysis of All Evaluations of StateFunded Preschool from 1977 to 1998: Implications for Policy, Service Delivery and Program Implementation. Early Childhood Research Quarterly, 15, 441-473.

Gormley, W. \& Gayer, T. (2003). Promoting School Readiness in Oklahoma: An Evaluation of Tulsa's Pre-K Program. Crocus Working Paper \#2. Available at: http://www.crocus.georgetown.edu/oklahoma.html, accessed 7/2/2004.

Gormley W. \& Phillips D. (2004). The Effects of Universal Pre-K in Oklahoma: Research Highlights and Policy Implications. Crocus Working Paper \#2. Available at: http://www.crocus.georgetown.edu/oklahoma.html, accessed 7/2/2004.

Groginsky, S. (2002). Child Care and Early Education Coordination in the States: A Statutory Overview. Denver, CO: National Conference of State Legislatures.

Groot, W. Maasen van den Bring, H., Dobblesteen, S. and van Mierlo, N. (2004). "The Economics of Early Childhood Education: a Survey, in C. Sofer (ed.), Human Capital over the Life Cycle. Cheltenham, UK: Edward Elgar. 15-35.

Hayes, C., Palmer, J. \& Zaslow, M. (1990). Who Cares for America's Children. Washington, DC: National Academy Press.

Head Start Bureau. (2003). Head Start Program Fact Sheet. Available at: http://www2.acf.dhhs.gov/programs/hsb/research/2004.htm. Accessed: 6/04.

Helburn, S. \& Bergmann B. (2002). America's Child Care Problem. New York: Palgrave.

Henry, G., et al. (2003). Report of the Findings from the Early Childhood Study: 20012002. Atlanta, GA: Andrew Young School of Policy Studies, Georgia State University.

Heymann, J., et al. (2004). The Work, Family, and Equity Index: Where Does the United States Stand Globally?. Boston, MA: Harvard School of Public Health. Available at: http://www.hsph.harvard.edu/globalworkingfamilies/. Accessed 8/25/2004.

Kamerman, S. (2000). Parental Leave Policies: An Essential Ingredient in Early Childhood Education and Care Policies, Social Policy Report, 14, 3-15.

Lee, C., Ohlandt, S \& Witte, A. (1996). Parents Receiving Subsidized Child Care: Where Do They Work?. Tallahassee, FL: Florida Children's Forum. 
Susanna Loeb, Bruce Fuller, Sharon Lynn Kagan, Bidemi Carrol, Judith Carroll, Jan McCarthy. (2003). Child Care in Poor Communities: Early Learning Effects of Type, Quality, and Stability. NBER working paper 9954. Available at www.nber.org/papers/w99454. Accessed 7/14/04.

Loprest, P., Schmidt, S. \& Witte, A. (2000). Welfare Reform under PRWORA: Aid to Children with Working Families?, Tax Policy and the Economy, 14, 157-2003.

Magnuson, K., Ruhm, C. \& Waldfogel, J. (2004). Does Pre-kindergarten Improve School Preparation and Performance? NBER working paper 10452. Available at www.nber.org/papers/w10452. Accessed 7/2/2004.

Marx, F. \& Seligson, M. (1988). The Public School Early Childhood Study: The State Survey. New York, NY: Bank Street College.

Masse, L. \& Barnett W. (2002). A Benefit Cost Analysis of the Abecedarian Early Childhood Intervention. Cost-Effectiveness and Educational Policy. Larchmont, NY: Eye on Education.

Mitchell, A., Stoney, L. \& Dichter, H. (2001). Financing Child Care in the United States. Kansas City, MO: Ewing Marion Kauffman Foundation.

Myers, M., et al. (2002). The Dynamics of Child Care Subsidy Use: A Collaborative Study of Five States. New York: National Center of Children in Poverty.

National Child Care Information Center. (2004). Early Care and Education Funding. Available: http://www.nccic.org/poptopics/ecarefunding.html. Accessed on 9/6/2004.

Novak, K. (1999). Review of State Funding for Head Start. St Paul, MN: Research Department, Minnesota House of Representatives.

OECD. (2000a). Early Childhood Education and Care Policy in the Flemish Community of Belgium. Available at: http://www.oecd.org/dataoecd/47/40/2479277.pdf. Accessed on $7 / 14 / 04$.

OECD. (2000b). Early Childhood Education and Care Policy in Sweden. Available at: http://www.oecd.org/dataoecd/31/17/31551259.pdf. Accessed: June 29, 2004.

OECD. (2001a) Early Childhood Education and Care Policy in Finland. Available at: http://www.oecd.org/dataoecd/52/27/2534770.pdf. Accessed: June 29, 2004.

OECD. (2001b). Starting Strong: Early Childhood Education and Care; United States. Available at: http://www.oecd.org/dataoecd/43/58/1942386.pdf. Accessed: June 30, 2004.

OECD. (2001c). Starting Strong: Early Childhood Education and Care. Paris: OECD 
OECD. (2002). Early Childhood and Education Care Profiles - Norway. Available at: http://www.oecd.org/dataoecd/44/14/1942347.pdf. Accessed: June 29, 2004.

OECD. (2004a). Early Childcare and Education Home Page. Available at: http://www.oecd.org/document/3/0,2340,en_2649_34511_27000067_1_1_1_1,00.html. Accessed: June 20, 2004.

OECD. (2004b). OECD Thematic Review of Education and Care Policy; Background Report; United States of America. Available at:

http://www.oecd.org/dataoecd/25/55/27856788.pdf. Accessed: June 29, 2004.

Office of Management and Budget. (2005). Budget of the United States Government Public Budget Database. Available at:

http://www.whitehouse.gov/omb/budget/fy2005/db.html. Accessed on 6/04.

Reynolds, Alan. (2002). Marginal Tax Rates. Available at:

http://www.econlib.org/library/Enc/MarginalTaxRates.html. Accessed on 7/14/04.

Reynolds, A. (2003). Prevention and Cost-Effectiveness in the Chicago Longitudinal Study of the Child-Parent Centers. presentation to Making Connections: A 2-daySchool Readiness Learning Symposium, Sacremento, CA, December 9-10, 2003. Available at: http://www.healthychild.ucla.edu/First5CAReadiness/Symposium/Arthur\%20Reynolds.p df. Accessed 7/5/2004.

Rolnick, A. (2004). A Conversation with Art Rolnick. The Evaluation Exchange, 10, 1617.

Ruhm, C. (1998). The Economic Consequences of Parental Leave Mandates: Lessons from Europe, Quarterly Journal of Economics, 113, 285-317.

Ruhm, C. (2000). Parental Leave and Child Health, Journal of Health Economics, 19, 931-960.

Shumacher, R., Greenberg, M. \& Lombardi, J. (2001). State Initiatives to Promote Early Learning. Washington, DC: Center for Law and Social Policy.

Schweinhart, L. (2001). Recent Evidence on Preschool Programs. Champaign IL: ERIC clearinghouse on Elementary and Early Childhood Education. Available at http://www.ericdigests.org/2002-2/preschool.htm. Accessed 7/02/2004.

Schweinhart, L, Barnes, H. \& Weikart, D. (1993). Significant Benefits: The High/Scope Perry Pre-School Study Through Age 27. Ypsilanti, MI: High Scope Press.

Smith, T., Kleiner, A., Parsad, B. \& Farris, E. (2003). Pre-kindergarten in the US Public Schools: 2000-2001. Washington, DC: US Department of Education. 
Stoney, L. \& Greenberg, M. (1996). The Financing of Child Care: Current and Emerging Trends, The Future of Children, 16, 83-102.

Tax Policy Center. (2000). Comparative Income Tax Rates, 2000. Available at: http://www.taxpolicycenter.org/TaxFacts/TFDB/Content/PDF/oecd_inctax_2000.pdf. Accessed on 7/15/03.

The Brookings Institution. (1999). Investing In Children. Available at: http://www.brookings.edu/comm/childrensroundtable/issue1.htm. Accessed: June 29, 2004.

The Urban Institute. (2003). Half of Working Families with Children Pay for Child Care - Nearly Three in Ten Receive Help with These Expenses. Available at: http://www.urban.org/Template.cfm?NavMenuID=24\&template=/TaggedContent/ViewP ublication.cfm\&PublicationID=8257. Accessed: July 16, 2003.

Trowbridge, M. \& Witte, A. (2004a). Estimated Federal Expenditures on ECE, 19612002. Working papers, Department of Economics, Wellesley College, Wellesley, MA.

Trowbridge, M. \& Witte, A. (2004b). Pre-K Programs in the US. Working papers, Department of Economics, Wellesley College, Wellesley, MA.

UNESCO Institute for Statistics. Percentage distribution of public expenditure on education. Available at:

(http://stats.uis.unesco.org/eng/ReportFolders/Rfview/explorerp.asp. Accessed on $7 / 15 / 03$.

US. Department of Labor Bureau of Labor Statistics. (2004). Consumer Price Index. Available at: ftp://ftp.bls.gov/pub/special.requests/cpi/cpiai.txt. Accessed on 6/04.

Postsecondary Education Opportunity. (2004). State and Local Tax Fund Allocations for Higher Education. Available at:

http://www.postsecondary.org/archives/Excel/PWTaxApprops.xls. Accessed on 6/04.

Watson, J. \& West, J. (2004). Full-Day and Half-Day Kindergarten in the Unites States. Washington, DC: National Center for Education Statistics.

Witte, A. \& Queralt, M. (2003). Take-Up Rates and Trade Offs after the Age of Entitlement: Some Thoughts and Empirical evidence for Child Care Subsidies. NBER working paper 8886. Available at www.nber.org/papers/w8886. Accessed 7/2/2004.

Witte, A. \& Queralt, M. (2003). Impacts of Eligibility Expansions and Provider Reimbursement Rate Increases on Child Care Subsidy Take-Up Rates, Welfare Use and Work. NBER working paper 9693. Available at www.nber.org/papers/w9693. Accessed 7/2/2004. 
Zigler, E. Finn-Stevenson, M. and Marsland, K. (1995). Child Day Care in the Schools: The School of the 21 ${ }^{\text {st }}$ Century. Child Welfare, 74, n6, 1301-26. 